遅く「動作性」の抽象は「もの性」の抽象より難かしい と報告されている。笠原（日本幼年教育協）は4・5才 児へのインストラクションの訨方を質し，幻览の熟知語 を用いた例題方式を用いたとの回答がなされた。しか し，よく工夫された実験方法であるだけに，課題の理解 そのものに関してやや問題があるという印象が残ったよ らである. 村石（国立国語研）は品詞概念の形成の他に 主語と述語などの概念の形成をどう考夏るかという質問 を提出，本実験では名詞＝主語，動詞＝述語といらかた ちで重複して招り今後は分離してゆきたいとの答がなさ れた. 村石 (145) は助数詞, とくに匹と頭をめぐって, 対象一単語とか単語間の意味にかかわる言語の系があり その系の習得の論理を探ろらとする事例的䂺究を報告し た、笠原は匹と頭など使い分けの基準の有無をたずね， 横地 (和光学園) は助数詞の閉題よりも自然数による 1 対 1 対応の教育が重要であることを主張したが問題があ まりに大きくなるため討論となるに到らなかった，清水 （146）については横地から知覚的推理と定義された課題 よりも困難な作業を現奏の子どもに行なっており，現実 的な開題を課題にえらぶ必要が指摘され，清水も全面的 な賛意を示した。河井（147）は言語構造獲得の 過程を 分析するにあたって, 言語構造が獲得されてくるにした がって文章記憶における構造的な愦りは減少すること， および，基本的文型が変換される度合いに応じて誤りは 增加すること，を発達的に検証しようとした。このた

\section{2 学}

211 対連合リストにおける意四対偶発学習〔II]

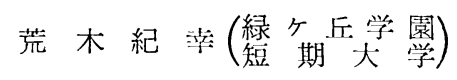

212 言語学留に批施課題要因の検討

$$
\text { 阿部千春 (東 京大学) }
$$

213 制限連想反応語の比較研究 一日・英・独を中心として一

永 沢 㕝 七(東京家政学院大学)

214 言語能力の分析的研究 (1)

$$
\begin{array}{r}
\text { O安藤公平 (日本大学) } \\
\text { 土屋守 ( ” ) } \\
\text { 岡村一成 (富士短期大学) }
\end{array}
$$

215 音の精神作業に及ぼす影響 一ながら視聴と学習成績一

$$
\text { 岩田紀 (四国女子大学) }
$$

め，肯定で能動態の平叙文を基本的文型（K) とし，暫 定的に 7 種の变换文をこれより作成し，その再生を調べ た. すなわち，K の否定・受身・疑問への変換とこれ らの組合せ変換を含む 7 種の文型を設定. 河井は文章記 憶の際に逐語的記憶よりも基本的文型の記憶が先行し, $\mathrm{K}$ 抢よび受身が文型として最も初期に獲得されること を示唆した. 永沢（東京家政大）は材料呈示の順序など 方法論について質し, 順序効果や被験者の飽さに対し適 切な考慮のあることが示された，雨角(長野保育専問院) は K からの変換により日常的でない文章となった材料 が用いられている点を教育者の立場から指摘したが，発 表者抢よび他の参加者から実験条件の僌密さの確保とい ら点から反論が行なわれた。多田（148）は認知発達に 抢ける ikonic な心理過程に関連させて映像の機能を明 らかにする必要を説き, 言語記号と対比して映像に技い ても semantics, syntax, pragmatics, に対応寸る問題 領域があるとしてテレビ映像の文法構造的な側面の認知 発達の実態を報告した。 SD 法により測定された情緒的 印象構造と材料の意味内容の上の構造の認知の雨面にお いて，ともに「図と地」の逆転があり文章の読み以上に 映像の読みには問題があることを指摘した，笠原は実態 に加えて教育作用を加えるアプローチをとる必要をあげ たが実験材料を単純化し被験者の年令水準を下げた段階 でそれを試みる作業を予定しているとの回答がなされ た。

（村不昭三・多田俊文）
216 学習プログラミングの実験的研究 第23報告 一集団学習の個人に及ぼす効果の検討一

○小池 栄 一(鶴川女子短期大学)

島田昌幸 (東京学芸大学)

河野義章 (" )

渡辺祥子(" )

217 学習プログラミングの実験的砳究 一学留の転移と文章䛃解力の関係について一

○渡 辺 祥子 (東京学芸大学)

河野義章 (" )

堀内敏夫 (" )

島田昌幸( " )

218 学習プログラミングの奏験的研究 ーリニアー・プログラムとブランチング・ プログラムの学習効果の比較— 


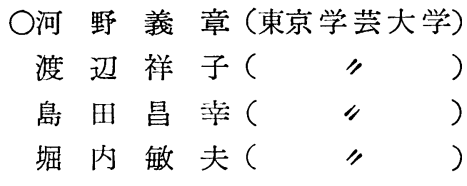

\section{I 全 体 的 特 徵}

(1) 学習効果, (2) 言語分析, (3) 学習プログラミン グの実験的研究の 3 領域にわけられている. 学習は, 対

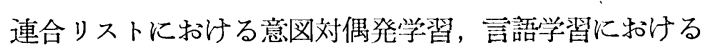
課題要因の検討. 音の精神作業に及ぼす影響〜ながら視 聴と学業成績. 言語分析では制限連想反応語の比較研究 一日・英語を中心として. 言語能力の分析的研究. 学習 プログラミングの実験的研究では、リニアープログラム とブランチングプログラムの学習効果の比較, 集団学習 の個人に及ぼす効果の検討. 学習の転移と文章理解力の 関係について研究発表された。

発表者全員参加し討議も活発におこなわれた。常時 50 名位の出席者があった．発表順位の変更が一つあり, 218 (河野) の発表が順位6になり 218 (小池) の発表 が順位 8 と入れかわった.

\section{II 討 論の内 容}

211 永沢（東京家政学院大）の質問：被験者の等質 性についてどのような配慮がなされたか. 荒木（緑ケ丘 学園短大) の答：1000 人位の大学生の中から random に選んだから特に考慮はしなかった．しかし内省報告に みられるよらに, この種の学習実験に経験はないものば かりである.

212 永沢 (東京家政学院大) の質問: 構造性が複雑 なほど学習が容易だといら結果の意味について. Chomsky のいら文の構造に抢ける deep structure といら.こ とと多少関係もあるが私の実験でも文が複雑なほど学習 が困難になったのに反対の結果はどういう意味か？阿 部千春（東京大)，複雑性といらことは経験が多いとい う意味である．永沢：表現を少し工夫すべきではない か. など指摘された。

213 小池（鶴川短大）の質問：刺激語の選択に関し て，普通名詞には差はないとしても，抽象名詞などで は，各国語によるニユアンスの差などないか？永沢 (東京家政学院大) の答：刺激語 “仕事” に対してドィ ツ語の反応語に Shule（学校）といら頻数が一番多く みられたが日本語・英語には全々みられなかった，日・ 英の場合も仕事に対して,つらいと一生彩命といら差が
みられた。 こらいら点を cross-culture 的見地で検討す ることが一つのねらいでもある.

213 梅本（京大）の質問：英語の work は名詞と もなり動詞ともなり得る。これを日本語で仕事と訳して しまって比較するところに問題はないか? 永沢 (東 京家政学院大) の答：そのようなことをできるだけ避 けようとするために制限連想を適用したのである. 即ち 刺激語 “仕事” に対して8 課題のもとに反芯語を書かせ た，例えば上位概念，形容詞，動詞，位温，部分などで ある.

213 安藤（日大）の質間：本研究ではアメリカの Thorndike Lorge の使用頻度によって刺激語が選ばれ ているが，それらを年のまま国際的な比較に用いてょ いものか? 永沢の答：これは日・米・独・西・伊の cross-culture 的調査なので米国が基準になって日本は 被比較国の一つになっている.

213 小池, 梅本, 安藤からの質間は cross-cultural の研究をする場合の, 比較の前提条件としての刺激語の 選択の基準や適切性が指摘された。永沢の答：国際 間の比較は，どこかを基準として刺激語を選択しなけれ ばならない. Thorndike Lorge の頻数表は，かなり大 規模な調査の結果なのでこれに基準を敃いた．その上， 刺激諸選択の場合は米・独・日（筆者）膟米中の研究者 が刺激諸について色々討議をして選択した。

213 荒木（緑ケ丘短大）被験者とくにドイッの被験 者について質問. 永沢の答：ドイッはアメリカの研究 班が一年間 Europe に出張してスペイン，伊太利の国々 と同じょうと調査春施した。

215 山下（上智大）の質問：（1）被験者のIQ ぞは検討されたか? 岩田（四国女子大）の答：知能 の上では違いがない，(2) 性差は認められるか? 岩 田の答：あまりない。

215 小池（鶴川女子短大）の質間：（1）ながら群一 非ながら群の区分に闔題はないか. またラジオとテレビ の視聴は分けて考えるべきではないか？（2）ながら勉 強法は，むしろ教育的には有効ではないか。

これに関連して山下（上智大）, 肥田野（東大）。 comment し, ながら学習については，はっきりした基 準の立てにくい点を指摘した.

肥田野（東大）の意見：生徒の 視聴時間や 視聴態度 とも関連づけて考慮した方がよい。河野（東京学大） ながら視聴と学業成績とを直接的に関連づける結論は少 し無理ではないか．梅本 (京大) “音の精神作業に及 ぼす影響”といら題目は, 本研究の内容加々て考攄の 
要ありなどの指摘がなされた.

218 小室 (東北大)：pre-test と post-test とは同 じ内容のものかをたずね，学習の効果を検討するには， pre-test と post-test の成績の差のみを閔題にするので は不充分ではないかを指摘した。

217 小林（都教委）の質問：工業高校の技能教育の 実例で， 1 年生ではプログラム学習により step by step に実施し，2 年生では長い文章による説明のテキストを 使用したところ，成績は低下した。プログラム学習で不 足したものは，別途に文章読解力を養うことで補充する 以外飞方法はないだろらか。渡辺 (東京学大) の答： 本実験の結果からは直接には答えられない。この問題に 関していえば, 本研究に用いられた学習転移テスト，読 解力テストそのものの妥当性や信頼性がむず十分に検討

\section{2 学}

221 発表取消

222 二次的課題が附加された場合の選択反応成績 一その学年差执よび教示時条件差の検討一

長塚康弘 (新潟大学)

223 回転追跡課題に於ける単一休喤効果

-WU 現象を中心比

○和田孝 (早稲田大学)

富田達宸( " )

小林 正太郎 (")

224 リズム再生とリズム再認について

○梅 本莣夫 (京都大学)

堀井昭子(")

225 追従学習に拈ける個人差

—Task Ability の問題—

福 島 脩 美 (東京学芸大学)

226 概念行動の基磷学留

1. 重複障害者の教育

その 1 盲ろら二重障害者の教育目的

○中島 昭 美 (東京水嗳大学)

井上早苗 (東京大学)

227 概念行動の基礎学習

1. 重複障害者の教育

その 2 盲ろら二重障害者の教育方法

○井上早苗 (東京大学:

中島昭美 (東京水痤大学)
される必要がないだろらか。

216 小室（東北大）の質問：組別にした場合, 学習 時に話しあった内容は何か. 末次 (中央鉄道学院) : 学習時間の割り当てはどらなっているかの質問あり, 松 浦 (大阪学大). $\mathrm{H}_{3}$ 群, $\mathrm{T}_{2}$ 群 (集団学習) の成績の算 出法について疑義が指摘された.

218 永沢（東京家政学院大）の質問：（1）ソシオメ トリーの効果か学習プログラミングの効果か, どちらが 影響しているか? （2）2.3人合議して結果をだすので は他の生徒と比較した場合成績がよいのは当然ではない か？小池（鶴川女子短大）の答：たしかにそら考劣 られるので retention などをみよらとしている.

（安藤公平・永沢幸七）

\section{習（2）}

\section{I 全 体 的 特 徵}

この部門にはいわゆる知覚運動学習に関する諸研究が 含まれている.この分野は最近の教育心理学における教 授学習発達関係のめざむし研究の発展に比して, これ まで比較的とり残されてきた感がある. 教育心理学の学 習関係の最近は, 発見学習や有意味学習との関連に扣い て, 概念学習や言語の学習などの方面に大方の関心が集 まっているようである.

しかし知覚運動関係の学習が教育心理学の枠組の中で も軽視できないことはいらまでもない，現に，教授学習 発達関係の諸研究に対して基本的枠組を提供しているピ アシシェやソ連心理学の体系はいずれも知覚や動作も非常 に重要視しているのである. 教育心理学の研究でも知覚 運動関係の基礎的研究を抜きにした発展は, 行詰る可能 性が大きい。もっともこれまでの教育心理学は, 普通児 の学校教育で, しか子基礎教科の学習を対象としていた ものが主流を占めていたので，成熟に規定される重みの 強い知覚運動学習が前面に浮び上ってこなかったともい 元よう. 知覚運動の学習は, 低い年令か, 特殊児童の教 育といら領域ではしめて問題とされていた。しかしこれ からは，それだけに止まらず，教育心理学の基礎研究と して,より重視されねばならないであろう。

\section{II 討論の内容}

長塚康弘の研究（222）は，児童の交通安全教育の基 
礎として選択反応について研究したものである．和田ら （223）と福島の研究（225）は回転盤追跡学習を用いて ウォーミングアップやレミニセンス等基楚理論的に追及 しょらとしたものである. 梅本の研究（224）はリズム 再生と再認の関係を調べたものである. 中島, 井上の研 究 $(226,227)$ は，これまで発表された盲靖涇者に対す る梅津八三らとの共同研究をさらに発展させたもので ある。

福島脩美の 発表（225）は回転盤追跡学習で，パフォ ーマンス量やレミニセンスが学習者の向性と相関してい るといら, 福島のこれまでに得た結果を再検討したもの で, 被験者の能力に応じて回転盤の速度を変えて実験す ると, 従来の結果に反し, 個人差の要因が有意でなくな ったといら報告である. 分散試行と集中試行の条件間に 差はあるが, 作業能力については, レミニセンスでも， パフォーマンスでも, 学習に拈いても差がみられなかっ た。また向性に関しても差がみられない.

この結果に対して, 「外向性と内向性で教示の受取り 方が異なるのではないか」（和田孝）とか, 「個人差 の測定を 1 回の測定で決定するのでなく, 定常な個人差 を測定することも考えられる」（梅本堯夫）などの意見 が出た. また Eysenck の consolidation 説に対して, 福島は賛成できないとのべた，運動学習に特ける個人差 の分析は Fleishman, E.A. (In Gagné, R.M. Learnig

\section{3 思}

311 幼児に拉ける量概念の把握

桜 田 光 男 (桜田坚童研究所)

312 幼稚園児および小中学生に批ける思考の 発達の研究 [1

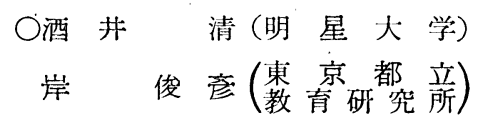

313 幼稚園児打よび小中学生に拊ける思考の 発達の研究 〔 I]

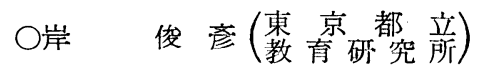

$$
\begin{aligned}
& \text { 酒井清 (明 星大学) }
\end{aligned}
$$

314 中学生の科学的思考の指導に関する研究 一慣性の法則について一

$$
\text { 帛田昌涼( 易本中大学校) }
$$

and individual differences, 1967, 165-191) らによっ て行なわれ，最近注目されている領域であり，今後の検 討が望まれる。

中島昭美, 井上早苗の発表 $(226,227)$ は盲龖二重障 害者の教育に関するものである.二重障害者は歩くこと もできず，家庭で㷃たままの状態でいて，保萑者に全面 的に依存していることが多いが，かれらに歩行を「学 習」させ, さらに「身振りサイン」を習得させて, 基本 的欲求のコミュニケーションを可能にし，自立への第一 歩を踏み出させたといら貴重な報告である.

この発表に対して多くの質問が笴せられたが，その答 をまとめると次のようである。これまで試及た二重障害 者の数は約 10 人で，年齢は 1 才から 7 才ぐらいにわた る. 約 2 週間で歩けるよらになるが, 即日に歩けるよう になるものもいる. 二重障害者で歩けないといらこと は，本来，歩けるようになっているにも拘らず，親が歩 けないものと決めているためと，「歩く」といらことを 二重障害者に伝達できないからである。つまり保護者の 無能力のために歩行できないのである.障害者の残され た感覚通路である触覚を通して適切な刺激を与えて指導 すれば, 歩行させることが可能である.この砳究は多く の示唆にとんだ知見を提供している.

（梅本堯夫・中島昭美）

\section{考（1）}

315 知識の獲得と体制化に関する発達的研究 (1)

$\begin{array}{ccc}\text { ○四 方 } & \text { 一実 } & \text { (京都教育大学) } \\ \text { 鈴 } & \text { 木 } & \text { 清 (東京教育大学) } \\ \text { 林 } & & \text { 保 (京都教育大学) }\end{array}$

316 知識の獲得と体制化に関する発達的研究 (2)

○渡 辺秀敏 (京都教育大学)

品川 不二郎 (東京学芸大学)

一谷疆 (京都教育大学)

317 知識の獲得と体制化に関する発達的研究 (3)

○野 村 庄 吾 (京都教育大学)

佐藤正 (東京学芸大学)

間 宮武(横浜国立大学)

318 知識の獲得と体制化に関する発達的研究 (4)

○哃 本夏木 (京都教育大学)

津留宏 (神户大学) 